\title{
NASKAH AJARAN ISLAM DALAM pencak silat ameng timbangan
}

\author{
MANUSCRIPT OF ISLAMIC TEACHINGS IN PENCAK SILAT AMENG TIMBANGAN
}

\author{
Oleh Agus Heryana \\ Balai Pelestarian Nilai Budaya Bandung \\ Jl. Cinambo 136 Ujungberung - Bandung \\ Email: agus.yana17@yahoo.co.id
}

\begin{abstract}
Abstrak
Pencak silat aliran Timbangan merupakan buah dari ajaran Islam yang bersumber pada naskah Timbangan yang ditulis oleh R. Moezni Anggakoesoemah pada tahun 1920-an. Masyarakat Jawa Barat, khususnya pecinta bela diri pencak silat, lebih mengenal Ameng Timbangan sebagai bela diri ketimbang sebuah ajaran mengenai pokok-pokok agama Islam. Padahal sesungguhnya Ameng Timbangan bukan tujuan akhir dari seorang penganut ajaran Timbangan. Ajaran Timbangan terdapat dalam teks naskah yang terdiri atas 3 bagian, yaitu (1) Gurinda alam majaji (Guaroma), (2) Iman Bener anu jadi Tetengger Allah Ta'ala (Ibtat); (3) Syareat Tarekat Hakekat Marifat (Syatahama). Keistimewaan naskah ini adalah tidak menguraikan sedikit pun mengenai gerak pencak silat. Bahkan sebaliknya mewajibkan para penganutnya untuk berakhlak mulia sebagai buah pemahaman teksnya. Guna mengetahui ajaran Timbangan yang terdapat dalam teks naskah digunakan metode analisis isi dengan mengacu pada jenis penelitian deskripsi. Diharapkan tulisan ini dapat memberi pencerahan sekaligus menjawab pertanyaan mengapa Ameng Timbangan sangat melarang merusak atau menyakiti lawan, dan mengapa tidak pula mempunyai jurus-jurus, baik menyerang maupun bertahan.
\end{abstract}

Kata kunci: R. Moezni Anggakoesoemah, Ameng Timbangan Guaroma, Ibtat, Syatahama,.

\begin{abstract}
Pencak silat (a kind of Indonesia's traditional martial art) of Timbangan is a result of Islamic teachings based on the manuscript of Timbangan written by $R$. Moezni Anggakoesoemah in 1920s. It is known better as martial art rather than as moral teachings. The teachings of Timbangan consist of three parts: (1) Gurinda alam majaji (Guaroma), (2) Iman Bener anu jadi Tetengger Allah Ta'ala (Ibtat); (3) Syareat Tarekat Hakekat Marifat (Syatahama). The author has analysed the content of the manuscript to study moral teachings of Timbangan. Hopefully, the research would give insight and answer the question of why it is forbidden in Ameng Timbangan to destroy or hurt the enemies and why there is no defence or attack movements in this martial art.
\end{abstract}

Keywords: R. Moezni Anggakoesoemah, Ameng Timbangan Guaroma, Ibtat, Syatahama 


\section{A. PENDAhuluan}

Pencak silat dalam tatanan kehidupan masyarakat tradisional Jawa Barat menduduki nilai strategis. Berbagai aspek kehidupan, terutama hal-hal yang berkaitan dengan aspek seni dan permainan tradisional (rakyat) berpijak pada gerak pencak silat (Heryana,1997:1) Dalam hal ini pencak silat menjadi prinsip dasar berkembangnya atau setidaknya memberi warna dan corak pada suatu seni atau permainan rakyat. Sehubungan hal itu dapat diamati pada bentuk-bentuk kesenian dan permainan rakyat seperti: Debus, Rudat, Gotong Singa atau Sisingaan, Benjang, Kuda Renggong, Longser, Adu Domba, Ketuk Tilu, Tari Sunda dan sebagainya.

Sesungguhnya pencak silat berasal dari budaya masyarakat rumpun Melayu. yang hidup dan berkembang di Indonesia, Malaysia, Singapura, dan Brunei Darussalam. Pada masa lalu tidak ada kesamaan di dalam menyebut atau menamakan pencak silat. Masyarakat di kepulauan Indonesia menyebutnya pencak saja tanpa tambahan kata silat. Sedangkan di Malaysia, Singapura dan Brunei Darussalam menyebutnya silat saja tanpa pencak. Kata pencak dan silat pada dasarnya mempunyai arti yang sama. Kata lain yang juga mempunyai arti sama dengan pencak dan silat, tetapi jarang atau mungkin tidak pernah digunakan lagi adalah gayung, gayong atau gayuang (IPSI,1990:14).

Selanjutnya untuk keseragaman penyebutan pada tanggal 18 Mei 1948, saat tokoh-tokoh nasional dan tokoh-tokoh pencak silat Indonesia mendirikan IPSI di Surakarta, kata pencak dan silat digabungkan menjadi satu kata majemuk, yaitu pencak silat. Hal ini diperkuat dengan akronim IPSI itu sendiri yang berasal dari Ikatan Pencak Silat Indonesia. Sejak itulah pencak silat menjadi istilah resmi di Indonesia.

Pencak silat atau di Jawa Barat sering disebut penca saja tanpa diikuti kata silat atau disebut juga maenpo. Kamus Sunda LBSS mengartikan penca adalah ngaran sarupa seni gerak badan pikeun ngabela diri, nama sebuah seni gerak badan yang bertujuan untuk membela diri. Upaya pembelaan diri manusia itu erat kaitannya dengan kemampuan mengerahkan kekuatan yang dimilikinya. Pengerahan potensi diri manusia berasal dari dua kekuatan, yaitu kekuatan lahir (jasmani) dan kekuatan batin (rohani). Kedua kekuatan ini kemudian bersatu dan membangun sebuah sistem bela diri yang khas sifatnya. Kekhasan sistem bela diri itu tercermin pada penempaan kekuatan lahir (fisik) berupa gerakan-gerakan penca yang telah disistematisasikan di dalam jurus-jurusnya. Oleh karena itu berbagai pola jurus telah tercipta dan diciptakan para pendekar penca (Heryana,1995:7). Sedangkan kekuatan batin berupa olahan-olahan pikiran, perasaan, imajinasi dan hal-hal lain yang berbentuk abstrak yang ada pada diri manusia seperti emosi dan naluri. Olahan kedua ini kemudian menampakkan bentuknya pada strategi, taktik, dan teknik suatu pencak silat. Dalam hal ini, pencak silat oleh 
Fadilakusumah (1998:3) diartikan "kerjasama yang harmonis antara kemampuan jiwa dengan raga yang digerakkan untuk tujuan membela diri melalui gerak khas Jawa Barat".

Pengerahan kekuatan jiwa berarti pengerahan kekuatan akal (rasio), daya khayal (imajinasi), perasaan (emosi) dan kemauan. Kekuatan-kekuatan ini diolah sedemikian rupa yang kemudian melahirkan gerakan-gerakan bela diri yang tersistemasikan pada jurus-jurusnya (pencak silat). Senada dengan arti tersebut, Rusyana (1996:96) mengartikan penca hakikatnya adalah "kemahiran teknis bela diri yang tidak semata-mata mengandalkan kekuatan jasmani, melainkan kecerdasan akal dan kepekaan rasa, yang diperoleh melalui latihan yang tekun". Selanjutnya, kekhasan sistem $^{1}$ bela diri itu ditentukan oleh sosio budaya dan falsafah ${ }^{2}$ atau ajaran yang berlaku pada masyarakat masing-masing pemilik/pendukung suatu ilmu bela diri. Misalnya, pendukung penca aliran Cimande berasal dari masyarakat petani atau pedagang yang berbeda dengan masyarakat bangsawan yang hidup di kalangan pemerintahan tradisional (kebupatian).

Alam yang keras dan ketidakamanan menuntut para petani-pedagang itu untuk berpakaian yang sesuai, yaitu yang tidak membatasi kebebasan bergerak cepat. Dengan demikian, celana sontog atau pangsi yang digabung dengan baju kampret sebagai pakaian mereka sehari-hari. Demikian pula akibat pada cara berpakaian itu berpengaruh juga pada aliran pencak silat yang tercipta dalam kelompok sosial yang mengenakannya. Gerakan-kaki dan tangan Cimande yang tuntas dan keras menjadi ciri aliran Cimande (Darmana,1978:26$30)$.

Di Jawa Barat itu sendiri, berdasarkan hasil penelitian Aliran-aliran Pokok ${ }^{3}$ Pencak di Jawa Barat (Darmana,1978) terdapat 3 (tiga) aliran pencak silat yang pokok. Artinya, aliranaliran atau sistem-sistem utama yang telah mapan yang sudah diakui keampuhannya dan cukup meluas pengikutnya. Selain itu juga telah menjadi sumber bagi perkembangan pencak silat dewasa ini, baik sebagai bela diri, olah raga, maupun seni. Ketiga aliran pokok pencak silat tersebut adalah aliran Cimande, aliran Cikalong, dan aliran Timbangan. Ketiga aliran pokok penca itu masing-masing memiliki jurus dan prinsip berbeda antara satu dengan yang lainnya.

\footnotetext{
${ }^{1}$ Sistem adalah suatu kesatuan yang terdiri atas bagian-bagian dan yang kalau bagian-bagian tersebut diubah atau dirusak, maka kesatuan itu pun akan rusak. Jika suatu pencak silat merupa kan suatu sistem, maka pencak silat itu akan terdiri atas beberapa bagian yaitu: filsafatnya, strateginya, taktiknya dan tekniknya. Seandainya dalam suatu sistem terjadi pertentangan atau ketiadaan persesuaian antara filsafat dan strategi atau taktik atau teknik, maka sebagai sistem pencak silat itu menjadi rusak.

${ }^{2}$ Falsafat suatu sistem pencak silat adalah jawaban-jawaban terhadap.pertanyaan asasi tentang apa pencak silat itu, untuk apa dan sebagainya. Dalam suatu sistem pencak silat, filsafat akan menentukan strategi, taktik dan teknik.

${ }^{3}$ Sebutan aliran pencak silat hendaknya ditafsirkan sebagai sistem.
} 
Aliran Cimande dicetuskan oleh Eyang Kahir atau Abah Kahir atau ayah Kahir. Dinamai penca Cimande karena murid-murid Ayah Kahir berlatih di kali Cimande. Ayah Kahir meninggal di Bogor dan dimakamkan di Kampung Sareal pada tahun 1825. Dewasa ini aliran Cimande berpusat di Kampung Tarikolot Kecamatan Caringin Kabupaten Bogor. Ayah Kahir meninggal di Bogor dan dimakamkan di Kampung Sareal pada tahun 1825.

Aliran Cikalong dicetuskan oleh Raden Haji Ibrahim. Rd Haji Ibrahim adalah seorang pecinta ilmu (penca). Dimana pun ada guru penca, ia selalu mendatanginya untuk berguru. Hasil berguru itu kemudian diolah sedemikian rupa hingga menghasilkan penca yang berbeda dengan yang ada. Penca yang diperolehnya itu kemudian dinamai para pengikutnya sebagai penca aliran Cikalong. Disebut demikian sebab ia tinggal di Cikalong, Cianjur.

Aliran Cimande dan Cikalong memiliki persamaan dalam pola pembelajarannya, yakni bermula dari penguasaan gerak dasar hingga menjadi sebuah susunan jurus. Tahap berikutnya adalah pemberian pelajaran kerohanian yang berfungsi sebagai pengendali penggunaan pencanya. Pada tahap pemberian pelajaran kerohanian ini diberikan pengajaran berupa ajaranajaran moral yang dirumuskan dalam bentuk talek $^{4}$ (sumpah.janji pendekar).

Ajaran moral pada penca aliran Cimande dan Cikalong diberikan setelah atau bersamaan dengan pelajaran jurus-jurusnya. Fungsinya sebagai "pelengkap" dan tidak berkaitan dengan gerak jurus aliran penca tertentu. Tanpa disertai ajaran moral pun seseorang dapat mempelajari kedua aliran penca tersebut. Dalam hal ini ajaran moral bukan sebagai sumber lahirnya gerak penca aliran Cikalong dan Cimande. Sedangkan aliran Timbangan berpola "balik sungsang", yaitu berawal dari penguasaan ajaran kerohanian yang kemudian dilanjutkan pada penguasaan gerakan. Oleh karena itu, Timbangan sendiri menurut para penganutnya, bukanlah aliran pencak silat, melainkan suatu bela diri mandiri terpisah dari pencak silat. Hanya di kalangan ahli-ahli pencak silat saja Timbangan disejajarkan dengan aliran-aliran pencak silat lain, karena memang kebanyakan yang mempelajari Timbangan itu sebelumnya telah mempunyai latar belakang pencak silat.

Ciri umum sebuah bela diri adalah menjatuhkan atau merusak lawan sampai tak berdaya. Guna mencapai hal itu diperlukan strategi dan taktik perkelahian yang sistematis. Di dalamnya terjadi proses pengolahan kekuatan, cara berlatih dan melatihkan teknik-teknik tertentu untuk melumpuhkan lawan. Pendek kata setiap jurus yang dilatih mengarah pada melumpuhkan

\footnotetext{
${ }^{4}$ Patalékan adalah sumpah atau janji seorang pemenca. Setiap perguruan penca atau padepokan memiliki Patalékan. Oleh karena itu, setiap Patalékan akan berbeda antara satu padepokan dengan padepokan lainnya. Perbedaan ini sangat bergantung kepada guru besar penca setiap padepokan. Meskipun banyak perbedaan, intisari Patalékan mempunyai kesamaan. Yakni berisi sumpah pemenca untuk berbuat kebajikan. Misalnya, salah satu tujuan aliran penca Cimande adalah terwujudnya sikap dan perilaku hidup serta amal perbuatan Keluarga Besar Pencak Silat Cimande (KBPS Cimande) yang berpedoman kepada Talek (Petunjuk Pembinaan Pencak Silat Cimande, $t \mathrm{t}$ : 4)
} 
lawan. Berbeda dengan hal itu semua, Ameng Timbangan sangat "mengharamkan" merusak lawan. Gerak memukul, menyikut, menendang merupakan gerak untuk menyakiti lawan; dan hal itu semua dilarangnya.

Bagi seorang murid Timbangan berlaku prinsip "Jika diri dipukul merasakan kesakitan, maka orang lain pun akan merasakan hal yang sama". Perkelahian dalam pandangannya tidak lebih dari "memperlakukan seorang anak yang merajuk" untuk menginginkan sesuatu. Oleh karena itu, sangat terlarang untuk menyakitinya apalagi merusaknya. Gerakan yang digunakannya tidak lain adalah gerakan menghindar atau mengalirkan tenaga dengan tujuan menyelamatkan sang anak. Jadi, tindakan penyelamatan lawan merupakan ciri khas Ameng Timbangan.

Ada beberapa keunikan penca aliran Ameng Timbangan, yaitu sebagai berikut:

1. Tidak mempunyai jurus-jurus tertentu.

2. Perusakan atau menyakiti lawan; memukul, menendang, atau gerakan lain untuk menyakiti lawan sangat terlarang.

3. Tujuannya untuk menyelamatkan : silih salametkeun. (saling menyelamatkan)

4. Bersumber pada ajaran Islam yang terdapat dalam teks naskah Timbangan.

Ameng Timbangan lahir di Bandung dengan pendirinya adalah Rd. Moezni Anggakusumah, putra Rd. Haji Adra'i, seorang Penghulu Kepala di Sumedang. Ia dilahirkan di Sumedang pada bulan Oktober 1887. Pada masa mudanya, ia aktif di organisasi Syarikat Islam di Bandung. Namun, karena sifatnya yang kritis terhadap masalah sosial politik pada waktu itu, maka pada tahun 1919 Pemerintah Belanda menangkap dan memenjarakannya di penjara Banceuy.

Di dalam penjara, ia banyak bergaul dengan tokoh pergerakan lain. Mereka sering berdiskusi mengenai keadaan bangsanya. Satu kelebihan Rd. Moezni Anggakusumah adalah ia tidak hanya dapat melihat masalah bangsanya dengan kacamata politik, tetapi juga dengan kacamata filsafat. Dengan melalui perenungan filsafat itulah Rd. Moezni Anggakusumah menemukan suatu cara agar manusia selamat dalam menjalankan hidupnya di dunia yang fana ini.

Hasil renungannya dibukukan dalam tiga buah kitab berbahasa Sunda yang disusun dalam bentuk guguritan, yaitu Guaroma (Gurinda Alam Rohani Majaji), Ibtat (Imam Bener Tetengger Allah Ta'ala) dan Satahama (Sareat, Tarekat, Hakekat, Ma'rifat). Lahirnya kitab ini dianggap sebagai lahirnya sistem bela diri Timbangan karena intisari aliran Timbangan berada dalam pemahaman teks tersebut. Tanpa penguasaan teks yang baik dan benar akan menyebabkan Timbangan sebagai bela diri kehilangan ruh-nya. 
Teks naskah Timbangan itu sendiri bukanlah sebuah petunjuk dalam melakukan gerakan atau jurus-jurus tertentu, melainkan sebuah teks ajaran yang menguraikan hubungan manusia dengan Tuhannya yang mengimbas pada hubungan antarsesama manusia. Dalam pada itu, pemahaman atas teks memerlukan wawasan luas dalam bidang ajaran agama Islam dan konteks budaya yang berlangsung saat teks itu ditulis. Hal itu disebabkan sifat teks itu sendiri yang berisi ajaran agama.

Uraian di atas memunculkan masalah mengapa teks Timbangan menjadi intisari seluruh gerak-lahir aliran Ameng Timbangan.

Maksud penelitian adalah mengungkapkan nilai ajaran moral yang terkandung di dalam teks Timbangan.

Penelitian ini diharapkan menjadi sarana beribadah kepada Allah. Tidaklah Allah menciptakan makhluk itu dengan percuma atau sia-sia. Semuanya mempunyai makna yang semuanya pula memerlukan perenungan mendalam guna mengetahui dibalik fenomena itu semua. Manusia diciptakan semata-mata untuk beribadah. Jika demikian dapatkah kita "beribadah" melalui penca? Jika kita beranggapan ibadah hanya terbatas pada pengertian ritualitas agama saja seperti rukun Islam ( syahadat, shalat, puasa, zakat dan ibadah haji); jelas penca tidaklah termasuk ke dalamnya, tetapi apabila kita memandang pengertian ibadah lebih kepada upaya seseorang untuk mencari keridoan-Nya, maka penca, khususnya Ameng Timbangan dapat masuk ke dalamnya.

Berkaitan dengan tujuan penelitian di atas, maka metode yang digunakan pada penelitian ini adalah metode deskripsi analitik, yakni suatu metode yang memaparkan data-data apa adanya yang kemudian dianalisis sesuai dengan kebutuhan. Selain itu dilakukan pula teknik pengumpulan data berupa observasi partisipasi/pengamatan terlibat serta komunikasi langsung dalam bentuk wawancara. Sumber data lain yang sifatnya sekunder adalah kepustakaan. Kepustakaan, diperlukan untuk menunjang data penelitian tentang kepercayaan masyarakat yang diperoleh melalui wawancara. 


\section{B. HASIL DAN BAHASAN}

\section{Kelahiran Ameng Timbangan ${ }^{5}$}

Pencetus Timbangan adalah Raden Moez'ni Anggakoesoemah ${ }^{6}$. Beliau dilahirkan di Sumedang pada suatu hari di bulan Oktober 1887. Ia adalah putra Raden Adro'i, Penghulu Kepala Sumedang. Pendidikan yang didapat dari lingkungan keluarga memungkinkan bagi dirinya untuk memiliki sikap, pandangan dan pendirian yang tegas tentang berbagai masalah yang ada di lingkungan masyarakat sekitarnya pada awal abad ke-20. Salah satu hal yang menarik perhatiannya adalah nasib bangsanya, masyarakat pribumi ketika itu. Ia menyaksikan banyak ketidakadilan. Sebagai seorang yang mendalami aspirasi agama, khususnya agama Islam, ia tidak bisa berpangku tangan. Oleh karena itu, ia memasuki organisasi politik Syarikat Islam di Bandung.

Raden Moez'ni Anggakoesoemah berpendapat, bahwa keadaan yang buruk yang diderita bangsanya adalah akibat dari kebijaksanaan-kebijaksanaaan dan tindakan-tindakan kolonial Belanda pada saat itu. Pendapatnya ini tidak hanya mendorong memasuki organisasi politik, tetapi juga dia tidak sudi bekerja pada pemerintah Belanda. Itulah sebabnya, ia mencari nafkah dengan bekerja pada perusahaan swasta, walaupun kesempatan menjadi pegawai pemerintah terbuka baginya, karena ia seorang putra pegawai pemerintah ketika itu.

Aktivitas di organisasi Syarikat Islam adalah memimpin koperasi organisasi. Selain itu, ia pun memberikan penerangan-penerangan tentang berbagai keadaan dan masalah kepada para anggota lainnya. Pandangan-pandangannya atas kehidupan sosial masyarakat dianggap berbahaya oleh Pemerintah Belanda, maka pada tahun 1919, ketika ia berusia 32 tahun, Pemerintah Belanda menangkapnya dan memenjarakannya di penjara Banceuy. Tindakan Pemerintah Belanda bukannya melemahkannya, namun justru mempertegas dan memperjelas sikap dan pendirian-pendirian yang dianut semula.

Penjara bagi Raden Anggakoesoemah merupakan ajang pertemuan dengan anggotaanggota politik lainnya yang banyak tumbuh pada masa pergerakan. Mereka adalah kawan Raden Anggakoesoemah untuk berdiskusi. Melalui diskusi-diskusi itulah pandangan dan pendiriannya semakin lama semakin teguh.

\footnotetext{
${ }^{5}$ Tulisan ini bersumber pada draf Laporan Penelitian Aliran-aliran Pokok Pencak Silat Jawa Barat yang ditulis oleh Nana Darmana,dkk. Proyek Penelitian dan Pencatatan Kebudayaan Daerah Departemen Pendidikan dan Kebudayaan 1977 - 1978. Dalam media cetak pun buku ini menjadi rujukan utama, seperti terdapat pada majalah Jurus No. 15 -Tahun I-3 Januari - 16 Januari 2000; termasuk pula situs internet: http://silatindonesia.com/2007/05/timbangan/

${ }^{6}$ Nama lengkap Raden Moezni Anggakoesoemah, tetapi dalam keseharian (nama panggilan) disebut Raden Anggakoesoemah. Hal ini didasarkan catatan Padepokan Penca Daya Sunda
} 
Raden Anggakoesoemah seorang yang cerdas. Pada usia masih muda kepandaiannya sebagai orang pergerakan sudah hampir menyamai tokoh berpengalaman saat itu. Pandangan Raden Anggakoesoemah dalam dunia pergerakan politik masa itu memiliki kekhasan. Ia tidak melihat masalah-masalah bangsanya dengan kacamata politik, akan tetapi memandangnya dari sisi kehidupan manusia atau kearifan.

Raden Anggakoesoemah merenungkan persoalan-persoalan di masyarakat yang penuh dengan berbagai kepincangan. Renungan-renungannya itu membuahkan kesimpulan, bahwa sumber kepincangan itu terletak pada diri manusia itu sendiri, yakni "manusia tidak memiliki dasar hidup yang kuat". Oleh karena itu, dasar hidup yang kuat itu harus ditemukan dan diajarkan kepada sesama bangsa Indonesia. Dalam usaha pencaharian itu beliau menemukan trilogi "cageur-bener-bageur" (sehat jasmaniah - berdiri di fihak kebenaran - baik hati). Kalau masyarakat Indonesia telah memiliki sifat-sifat seperti itu, maka bangsa Indonesia akan dapat "membela dirinya" terhadap "serangan" bangsa lain.

Kesimpulan atas hasil renungan mendorong Raden Anggakoesoemah untuk memperkokoh pandangan hidup dan menyebarkannya kepada kawan-kawan di dalam penjara itu. Usahanya ini mendapat penunjang yang kuat dari bakatnya membuat guguritan (sajak Sunda). Banyak di antara kawan-kawan Raden Anggakoesoemah mengumpulkan guguritan tersebut yang keseluruhannya meliputi tiga buku, yaitu buku I Guaroma, buku II Ibtat, buku III Syahatama.

Buku yang pada intinya berisi trilogi "cageur-bener-bageur" ini mengajarkan agar setiap orang memiliki sikap pendirian yang kuat hingga dalam hidup sehari-harinya terhindar dari itikad buruk seperti mengambil keuntungan dari kesukaran orang lain, memfitnah, berlaku curang, merendahkan orang lain dan sebagainya. Hanya kalau dapat membela diri dari kecenderungan-kecenderungan jahat seperti itulah, maka seseorang menjadi kuat secara rohani. Kalau setiap pribadi dalam setiap bangsa kuat, maka akan kuat pula seluruh bangsa.

Lahirnya buku-buku guguritan itu dianggap sebagai lahirnya sistem bela diri aliran Timbangan, karena sejak itulah dimulainya latihan-latihan pembelaan diri terhadap serangan yang ditujukan kepada rohani. Latihan-latihan itu dilakukan dalan bentuk diskusi sesama tahanan. Melalui usaha seperti itu tidak sedikit kawan-kawan Raden Anggakoesoemah menyatakan bahwa manusia tidak hanya bersifat batin, akan tetapi juga bersifat jasmani. Di pihak lain Raden Anggakoesoemah melihat sendiri, bagaimana dalam kehidupan penjara orang lemah berada di pihak yang benar. Orang-orang yang baik, tetapi lemah secara jasmani ini sering diperlakukan oleh orang-orang jahat di luar batas perikemanusiaan. Itulah sebabnya, Raden Anggakoesoemah mulai memikirkan segi jasmani dari sistem bela diri Timbangan yang pada masa itu masih bersifat rohani. 
Namun, sebelum gagasan pembelaan diri Timbangan yang bersifat jasmani tercipta, pemerintah kolonial Belanda beranggapan Raden Anggakoesoemah terlalu berbahaya bila berada di penjara Banceuy. Ia harus dicegah menyebarkan gagasan-gagasan melalui diskusidiskusi kepada sesama tahanan. Itulah sebabnya Raden Anggakoesoemah dipindahkan ke penjara Sawahlunto, Sumatera.

Pemindahan Raden Anggakoesoemah ke Sawahlunto ternyata mempercepat tumbuh dan berkembangnya sistem bela diri Timbangan bagian jasmaninya. Di dalam penjara Sawahlunto terkumpul penjahat-penjahat kelas berat, yaitu perampok dan pembunuh. Pembunuhan antara sesama pesakitan adalah hal yang biasa. Akan tetapi hati nurani Raden Anggakoesoemah sebagai orang yang beradab dan berbudi luhur tidak dapat menerima keadaan itu. Maka renungan-renungan yang dibawanya dari Bandung terus diolah. Pandangan hidupnya diusahakan menjelma dalam bentuk lahiriah, berupa gerakan-gerakan bela diri, dan kemudian dikenal bernama Timbangan.

Pada awal terciptanya sistem bela diri Timbangan sedikit sekali orang yang mau mempelajarinya. Bukan saja masyarakat penjara relatif lebih kecil, akan tetapi dengan sendirinya suatu ajaran yang berisikan sikap hidup dan budi pekerti yang luhur itu tidak akan mendapat tanah yang subur di hati para penjahat. Mudah dimengerti apabila hanya beberapa orang saja yang mau belajar, khususnya sesama kawan tahanan Raden Anggakoesoemah.

Suatu hari terjadilah peristiwa yang memberi dorongan sangat besar pada pertumbuhan sistem bela diri Timbangan. Peristiwa yang dimaksud adalah adanya orang gila yang mengamuk dan mengakibatkan tahanan-tahanan lain cedera. Dalam kejadian ini para tahanan disuruh berlindung dan petugas penjara mulai membidikkan senapan ke arah orang gila tersebut.

Raden Anggakoesoemah mendapat ilham. Peristiwa itu dimanfaatkan untuk menguji beberapa gagasan yang berhubungan dengan bela diri Timbangan. Ia ingin menguji gerakangerakan yang telah lama dilatihkan pada diri dan pada kawan-kawannya itu apakah dapat diandalkan atau tidak. Di samping itu beliau pun harus meyakinkan dirinya bahwa orang yang berakal sehat akan mengalahkan orang gila.

Pikiran lain pun muncul seandainya ia dapat menangkap orang gila itu, ia akan memperoleh kekuatan dan wibawa untuk memperbaiki keadaan penjara yang buruk. Wibawa ini dapat dimanfaatkan untuk menanamkan kekuatan rohani seperti yang menjadi inti sistem bela diri Timbangan. Dengan kekuatan rohani itu diharapkannya keadaan penjara menjadi tenteram, orang-orang saling hormat-menghormati, jauh dari dengki dan saling merugikan sesama kawan. Dengan pikiran-pikiran seperti itulah Raden Anggakoesoemah tampil menghalangi orang gila yang mengamuk walaupun para petugas melarangnya. Ternyata 
kemudian, bahwa hasil latihan-latihannya itu membuahkan hasil. Orang gila itu berhasil digiringnya memasuki selnya kembali.

Akibat tindakan itu terjadi dua hal yang bertentangan. Pertama, para petugas menjadi hormat dan menaruh perhatian; kedua, para tahanan ada yang ketakutan dan ada juga yang penasaran ingin mencoba kepandaian Raden Anggakoesoemah. Mereka yang penasaran ini tampaknya tidak tahan lagi untuk mencoba kepandaiannya Raden Anggakoesoemah. Mereka menantang berkelahi, namun dengan sabar Raden Anggakoesoemah membujuknya agar tidak bersikap demikian. Sikap Raden Anggakoesoemah itu disalahartikan sebagai pertanda takut kepada mereka. Akhirnya, terpaksa Raden Anggakoesoemah melawan mereka. Perkelahian Raden Anggakoesoemah dengan para jagoan (tahanan) bukan saja mengalahkannya, bahkan menyadarkannya. Setiap serangan yang mereka lancarkan dihindarkan sedemikian rupa hingga Raden Anggakoesoemah bisa merebut posisi yang baik. Pada posisi itu ia dapat menyerang dan mencelakakan lawannya, tetapi tidak dilakukan. Akhirnya mereka menyadari sesungguhnya mereka sudah kalah, hanya saja Raden Anggakoesoemah tidak bermaksud jahat pada diri mereka. Dalam cara demikianlah mereka akhirnya menjadi sahabat sekaligus berusaha mengubah budi pekertinya yang buruk.

Tahun 1923 Raden Anggakoesoemah dilepaskan dari penjara. Setelah kembali ke Bandung, ia tidak mengadakan latihan-latihan terbuka karena keadaan tidak mengizinkan. Namun, tahun 1928 yaitu setelah terjadinya pemberontakan komunis, Raden Anggakoesoemah mengadakan latihan-latihan terbuka. Di antara murid-muridnya, banyak anggota pemuda penggerakan. Selain itu terdapat pula mata-mata pemerintah Kolonial Belanda yang mengikuti latihan untuk memata-matainya. Pemerintah Kolonial Belanda mencurigai latihan-latihan itu sebagai kedok pertemuan kaum pergerakan. Para mata-mata tidak menyadari pelajaranpelajaran rohani-jasmani yang diberikannya dapat mengubah cara pandang seseorang. Oleh karena itu, banyak mata-mata Belanda yang menjadi sadar dan berbalik melawan tuannya. Raden Anggakoesoemah pun terlepas dari bahaya penangkapan kembali. Latihan-latihan itu terus berlangsung sampai tahun 1942 hingga pemerintah kolonial Belanda menyerah kepada pasukan bala tentara Jepang.

Perkembangan sistem bela diri Timbangan tidak berkembang luas seperti Cimande atau Cikalong. Penyebabnya tidak lain karena memerlukan dasar-dasar kerohanian yang kuat serta wawasan agama (Islam) yang dalam. 


\section{Teks Naskah Timbangan}

Teks naskah Timbangan sebagaimana dikemukakan di awal tulisan terdiri atas 3 (tiga) ${ }^{7}$ teks, yaitu: (1) Gurinda alam majaji (Guaroma), (2) Iman Bener anu jadi Tetengger Allah Ta'ala (IBTAT); (3) Syareat Tarekat Hakekat Marifat (SYA-TA-HA-MA). Ketiga naskah tersebut ditulis dalam bentuk puisi (guguritan), kecuali bagian Guaroma ditulis dalam dua bentuk, yaitu prosa dan puisi.

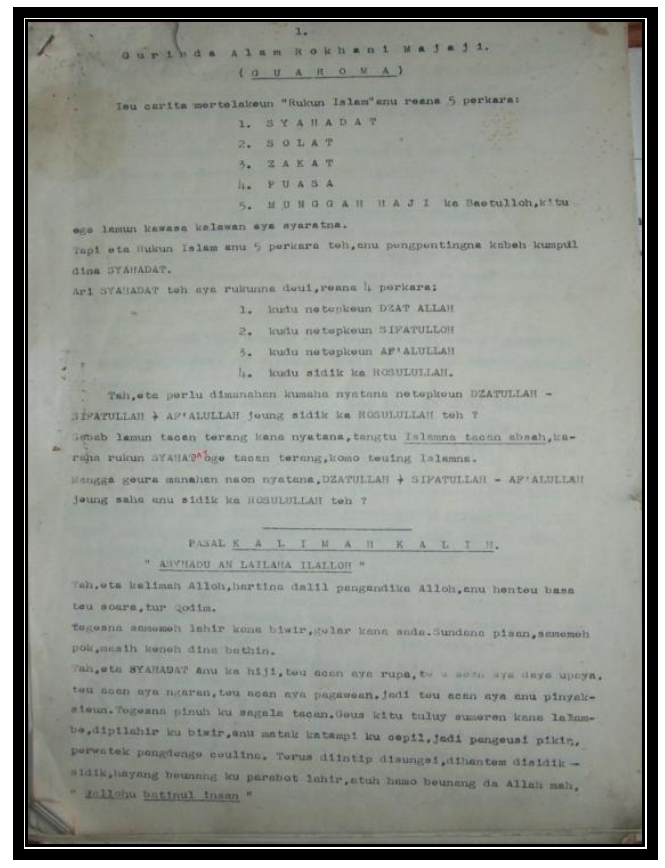

Naskah Ameng Timbangan

\section{a. Prosa}

Bentuk prosa merupakan uraian naratif yang berfungsi sebagai pengantar dalam memahami Timbangan. Biasanya guru Timbangan melakukan tanya-jawab dengan orang yang ingin belajar Ameng Timbangan dan hal itu dilakukan melalui gunem catur (diskusi tanya jawab). Isi pembicaraannya mengenai tujuan dan motivasi mempelajari Timbangan. Biasanya gunem catur berlangsung beberapa kali pertemuan, bahkan kadang-kadang berjalan dalam beberapa bulan. Hal itu sangat bergantung kepada kemauan dan kesungguhan orang yang bersangkutan. Apabila proses ini berjalan mulus, tidak lama lagi ia akan diajarkan gerakan-gerakan Timbangan. Namun demikian, tidak jarang "para pencari" Timbangan kalah sebelum bertanding. Baru sekali atau beberapa kali pertemuan sudah tidak sanggup mengikuti

\footnotetext{
${ }^{7}$ Gan Ema atas izin R. Mugni Anggakoesoemah menambahkan Ameng Timbangan-sebagai sistem bela diri- menjadi tahap keempat (Kudjang TAUN V No. 256)
} 
"acara" gunem catur itu. Berikut adalah cuplikan gunem catur dengan Kang Aom ${ }^{8}$ yang penulis lakukan dalam menelusuri naskah Timbangan.

Bapa teh ngahaja nalek, da sok rupa-rupa kahayang jalma mah. Aya nu hayang bisa gelut; da dianggapna Timbangan teh keur gelut. Enya eta ge sok dipake diadu, tapi lain ka dinya tujuanana. Baheula, pun aki, nyiptakeun timbangan teh lain keur gelut, jeung deuih da teu aya pangajaran gelut. Eta cenah sok aya nu nyebutkeun timbangan teh elmu nu luhur, dumeh sawatara lawanna ragrag ku timbangan; eta mah polahna sorangan bae. Ku lantaran kitu perlu heula dilelempeng naon ari timbangan nu saenyana teh.

(Bapa sengaja bertanya, sebab keinginan orang berbeda-beda. Ada yang ingin bisa berkelahi sebab menurutnya timbangan itu untuk berkelahi. Iya itu pun kadangkadang dipake berkelahi, tetapi bukan itu tujuannya. Dulu, kakekku, menciptakan Timbangan bukan untuk berkelahi, bahkan tidak ada sama sekali pelajaran berkelahi. Katanya ada yang mengatakan Timbangan adalah ilmu yang tinggi, sebab ada sebagian lawannya kalah oleh Timbangan. Itu sebenarnya karena perbuatannya sendiri. Oleh karena itu, perlu diluruskan apakah Timbangan itu sebenarnya).

Sesungguhnya teks Timbangan dalam bentuk prosa tidaklah persis sama dengan obrolan di atas, bahkan nyaris berbeda sama sekali. Namun, bukan berarti kandungan obrolan itu tidak bermakna atau tidak terarah. Hal pertama yang harus dilakukan guru Timbangan adalah membuka pikiran calon murid atas masalah-masalah pokok dalam Ameng Timbangan. Proses penempaan pikiran ini yang (biasanya) membuat bosan dan "pusing" sehingga mengurungkan niat seseorang untuk terus berlatih. Teks Timbangan dalam bentuk prosa berisi uraian Rukun Islam, Syahadat, dan Sifat 20 (Dua puluh).

\section{b. Puisi}

Naskah berbentuk puisi ditandai dengan pemakaian pupuh dalam teks naskah Timbangan. Istilah pupuh memiliki beberapa pengertian. Pertama, dalam istilah karawitan berarti bait atau pada, misalnya untuk sebutan sapupuh artinya sebait (satu bait) atau sepada. Kedua, aturan. Misalnya pada kata perang pupuh yang berarti perang yang beraturan. Ketiga, berarti lagu atau tembang. Pupuh Kinanti bisa diartikan lagu kinanti. Keempat, rangkaian bait yang memiliki pola yang sama. Pengertian ini diambil berdasarkan fungsi pupuh itu sendiri, yakni sebagai sumber pola untuk membuat rumpaka (syair) yang akan digunakan sebagai sarana penyajian tembang (lagu) (Atik Soepandi, 1986:3-4). Senada dengan hal itu Rosidi (1966:11) pun memberikan pengertian pupuh adalah puisi yang terikat oleh guru lagu, guru wilangan, dan guru gatra (jumlah baris). Guru lagu adalah suara vokal pada akhir baris; guru

8 Panggilan untuk Ahmad Darajat (60) putra H. R.Moehjidin Anggakoesoemah. Wawancara dilakukan tanggal Sabtu 3 Maret 2012 jam sebelas bertempat di Jl, Cibaduyut Lama Gg. Laksana. 
wilangan adalah jumlah suku kata pada setiap baris dan guru gatra adalah jumlah baris pada setiap pupuh tertentu.

Berdasarkan kuantitas pemakaian pupuh, teks naskah Timbangan termasuk ke dalam kelompok KSAD. KSAD merupakan akronim dari pupuh Kinanti, Sinom, Asmarandana, dan Dangdanggula.

\section{Kandungan Teks Timbangan}

Titik tolak pencak aliran Ameng Timbangan bersumber pada sejauh mana seorang murid mengerti, memahami, menghayati, dan mengamalkan ajaran yang terkandung dalam teks naskah Timbangan. Di sinilah peran penting uraian naratif yang dilakukan seorang guru. Tradisi gunem catur menjadi sangat penting dalam kerangka menjelaskan pengertian dan pemahaman teks-teks tertentu. Berikut adalah beberapa kandungan teks naskah Timbangan.

\section{a. Timbangan}

Pengertian Timbangan diperoleh melalui tradisi gunem catur. Seorang guru perlu menjelaskan mengenai hal itu, baik di awal, di tengah atau pun diakhir pertemuan. Itu semua sangat bergantung pada situasi, kondisi dan mood (suasana hati) sang guru. Menurut pendukung Ameng Timbangan, Timbangan artinya ukuran yang ditetapkan menurut ketentuan yang berlaku' ${ }^{9}$ Kesalahan menimbang akan menyebabkan ketimpangan dan perselisihan. Seorang pedagang menimbang sesuatu sesuai dengan berat yang diinginkan pembeli. Tentu jika timbangannya sesuai dengan yang diharapkan akan membuahkan ketenteraman dan kepercayaan yang tinggi dari pembelinya. Demikianlah manusia hidup di alam dunia ini memiliki ukuran yang sesuai dengan kemampuan dirinya. Tuhan memberikan sekujur tubuh manusia dengan ukuran-ukuran yang sesuai dengan kondisinya.

\section{b. Jelema jeung Manusa (Orang dan Manusia)}

Ajaran Ameng Timbangan sangat menekankan perbedaan antara jelema (orang) dan manusa (manusia). Kedua kata tersebut sangat berbeda.

Jelema henteu sarua jeung manusa. Jelema mah minangka "hasil campur" $t i$ indung bapa; tapi manusa mah diciptakeun ku Allah anu bersih tina sagala tabeat nu goreng; manusa mah jelema anu deuheus - deukeut ka Allah. Apan sok aya babasan leungit kamanusaanana lain kajelemaanana, pikeun manusa nu milampah pagawean teu luyu jeung aturan hirupna. Jadi, manusa mah boga harti positip ari jelema mah negatip. (Kang Aom; wawancara tgl $3 / 3 / 2012$ )

\footnotetext{
9 "Salah ku ukuran, bener ge ku ukuran. Baheula mah timbangan the sabada diloris (dipariksa) ku Jawatan Metrologi the sok dibere tanda $X$ (tera) minangka timbangan anu bener tur sah atawa "layak pakai". Hartina eta timbangan the moal nimbulkeun papaseaan atawa pacogrekan upama dipake ku jalma rea. Hasilna the katingtriman atawa "perdamaian". (Wawancara tanggal 3/3/2012)
} 
(Orang tidak sama dengan manusia. Orang adalah "hasil campur" antara ibu dan ayah, tetapi manusia diciptakan Allah dari yang bersih dari segala tabiat yang jelek. Manusa adalah orang yang dekat dan berbakti kepada Allah. Bukankah ada peribahasa hilang (sifat) kemanusiaannya, bukan "keorangannya", untuk manusia yang berbuat yang tidak sesuai dengan aturan hidupnya. Jadi, manusia mempunyai nilai positif sedangkan orang bernilai negatif).

Dalam teks (1) Gurinda Alam Majaji (Guaroma) pupuh Asmarandana (bait 3 - 5) dikemukakan, bahwa orang banyak tersesat jalan hidupnya karena tidak menggunakan dasar kemanusiaan. Kemanusiaan didasarkan pada kemuliaan dan kesabaran yang semuanya bermuara pada kekuatan iman kepada Allah. Jadi, sesungguhnya Timbangan itu berada pada wilayah kemanusiaan. Artinya belajar (ilmu) Timbangan berarti mempelajari ilmu kemanusiaan. Timbangan bukan ilmu untuk merusak, tetapi ilmu untuk saling menyelamatkan. Oleh karena itu seorang murid Timbangan harus mampu menelisik "kedalaman hati" setiap diri manusia. (Tah timbangan teh ayana dina kamanusaan, jadi diajar timbangan teh hartina mah diajar elmu kamanusaan. Timbangan mah lain elmu keur ngaruksak, tapi elmu keur silih salametkeun. Ku lantaran kitu kudu bisa ningali nepi ka jero-jroanana unggal diri).

\section{c. Rukun Islam}

Pokok utama pelajaran Ameng Timbangan diawali dengan pemahaman atas Rukun Islam, yaitu: Syahadat, Shalat, Saum (Puasa), Zakat, dan Ibadah Haji. Satu dari lima Rukun Islam memperoleh penekanan yang maksimal, yaitu Syahadat. Syahadat menurut teks ini mempunyai (empat) 4 rukun, yaitu

1) kudu netepkeun Dzat Allah (mesti menetapkan Dzat Allah)

2) kudu netepkeun Sifatullah (mesti menetapkan Sifatullah)

3) kudu netepkeun Af'alullah (mesti menetapkan Af'alullah)

4) kudu sidik ka Rosulullah (mesti jelas kepada Rosulullah)

Keempat rukun ini kemudian dijelaskan dalam teks-teks selanjutnya.

\section{d. Sifat Duapuluh : Sebuah Metode Ma'rifatullah}

Uraian mengenai hubungan-khusus antara hamba dan khaliknya sering tertuju pada masalah tunggal, yaitu Tuhan. Persoalan Tuhan pada hakekatnya persoalan yang menarik untuk dibicarakan. Sejak zaman Yunani dengan para ahli filsafatnya hingga dewasa ini, persoalan Tuhan tetap merupakan wacana yang aktual. Dalam kajian-kajian filsafat, istilah Tuhan sering diidentifikasikan dengan Yang Ada. Hal ini guna menunjukkan hubungan antara makhluk dengan khaliknya atau penciptanya. Adanya manusia bukanlah muncul dengan sendirinya, tetapi diadakan oleh Yang Ada. Banyak nama untuk menamai Yang Ada itu. 
Masyarakat tradisional menyebut Yang Ada (Tuhan) itu dengan sebutan Pangeran, Gusti, Hyang atau Hyang Tunggal.

Sementara itu, perubahan kepercayaan atau pergantian agama membawa konsekuensi yang cukup fundamental, yakni perubahan penyebutan nama Tuhan. Orang Islam akan menyebutnya Tuhan itu dengan nama Allah sebagaimana tersurat pada rukun Islam pertamanya, yakni Syahadat: Asyhadu anla ilaha ilallah, wa asyhadu anna Muhammadar rasulullah. Artinya: Aku bersaksi tak ada Tuhan kecuali Allah dan aku bersaksi Muhammad adalah rasul-Nya. Namun demikian dalam keseharian orang Sunda sering tanpa sadar merangkaikan ucapan Allah dengan penyebutan Gusti, maka jadilah sebutan Gusti Allah.

Sayid Sabiq (1999:31) mengemukakan bahwa bermarifat kepada Allah mempunyai dua cara, yaitu: pertama, dengan menggunakan akal fikiran dan memeriksa secara teliti apa-apa yang diciptakan oleh Allah Ta'ala yang berupa benda-benda yang beraneka ragam. Kedua, dengan mema'rifati nama-nama Allah Ta'ala dan sifat-sifat-Nya. Dalam kaitannya dengan teks Timbangan, penelusuran eksistensi Allah dilakukan melalui cara yang kedua, yaitu meneliti dan menghayati sifat-sifat Allah melalui Sifat 20 dan Asmaul husna. Jadi, nama-nama dan sifatsifat itulah yang merupakan perantara yang digunakan oleh Allah Ta'ala agar mahlukNya itu dapat bermarifat kepadaNya. Inilah yang dapat dianggap sebagai saluran yang membuat hati manusia dapat mengenal Allah secara spontan sebagaimana kutipan teks berikut:

Ari sifat dua puluh teh nya eta sifat kapangeranan pikeun jalma jalan iman ka Allah sangkan marifat (terang). Mimitina anu kudu diuji teh ku sifat dua puluh, AllahMuhammad - Adam. Ari Allah teh Ahadiyat, tegesna hiji memeh naon-naon; ibarat urang rek barang-dahar, samemehna salatri, tah lebah dinya.

(Sifat dua puluh adalah sifat ketuhanan untuk orang menuju iman kepada Allah agar bermarifat (mengenal-Nya). Awalnya yang harus diuji oleh Sifat dua puluh (adalah) Allah - Muhammad - Adam. Allah itu Ahadiyat (artinya) tunggal sebelum bilangan lain; semisal kita akan makan minum, sebelumnya terkena salatri ${ }^{10}$, nah di situlah tempatnya).

Secara garis besar teks berkisar pada uraian mengenai latar belakang mengenal diri sendiri. Bertitik tolak pada "dalil" man arofa nafsahu fa qod arofa rabbahu (Siapa yang mengenal diri sendiri maka ia akan mengenal Tuhannya). Persoalan kemudian melebar kepada sifat-sifat Allah yang berjumlah 20 sifat. Sifat 20 ini pun dikelompokkan ke dalam 4 bagian besar, yaitu : Nafsiah, Salbiah, Ma'ani, dan Ma'nawiyah. Nafsiah adalah sifat yang dengan sifat itu dapat membuktikan dzat Allah. Salbiah adalah yang menafikan (meniadakan) sifat-sifat yang tidak mungkin dan tidak layak untuk Allah. Sifat Ma'ani adalah memastikan yang disifati

\footnotetext{
${ }^{10}$ Merasa sakit kepala dan pusing karena kelaparan (belum sarapan)
} 
itu bersifat dengan sifat-sifat itu. Dan Ma'nawiyah adalah sifat yang lazim memastikan atau yang mengaktifkan sifat-sifat Ma'ani

Sifat duapuluh yang dimaksud dalam teks Timbangan adalah sebagai berikut:

1. Wujud (Ada)

2. Qidam (Dahulu tanpa permulaan)

3. Baqo (Kekal)

4. Mukhalafatu lilhawadits (Berbeda dengan yang baru)

5. Qiyamu binafsihi (Berdiri sendiri)

6. Wahdaniah (Maha Esa)

7. Kudrat (Kuasa)

8. Iradat (Berkehendak)

9. Ilmu (Mengetahui)

10 Hayat (Hidup)

11 Sama (Mendengar)

12 Basar (Melihat)

13 Kalam (Berkata)

14 Kodiran (Yang Kuasa)

15 Muridan (Yang Berkehendak)

16 Aliman (Yang Mengetahui)

17 Hayan (Yang Hidup)

18 Sami'an (Yang Mendengar)

19 Basiran (Yang Melihat)

20 Mutakaliman (Yang Berkata)

Keduapuluh sifat ini pun dikelompokkan ke dalam 4 (empat) bagian besar yaitu Nafsiah, Salbiah, Ma'ani, dan Manawiyah sebagaimana dikemukakan pada awal tulisan di atas.

\section{e. Ma'rifatullah : Mengenali Diri Sendiri}

"Yang Ada" adalah sesuatu yang abstrak yang tidak terpikirkan oleh akal manusia. Ketika manusia menyaksikan alam semesta dilanjutkan dengan pemikiran dan perenungan yang mendalam secara naluri akan timbul perasaan bahwa ada sesuatu yang menguasai alam ini. Kesan pertama adalah "Ada yang Maha Kuasa" (Hamka,1987:1). Kesan itulah yang tumbuh bilamana akalnya sudah mulai berjalan. Bahwa ada sesuatu kekuatan tersembunyi di latar belakang yang tampak ini, yang selalu dirasai adanya, tetapi tidak dapat ditunjukkan tempatnya. Manusia tidak dapat membohongi dirinya sendiri, bahwa ada sesuatu "kekuatan" yang tidak tampak yang mengatur alam semesta ini. Atas dorongan hati nurani, mereka menciptakan tuhan-tuhannya sekadar apa yang menjadi refleksi alam pikirannya. Artinya, dalam 
merefleksikan perasaan ketuhanannya itu pada awalnya, manusia tanpa mengikuti petunjuk dan tanpa kitab suci yang benar. Memang persoalan pokok yang menjadi bahan pemikiran para pemikir masa lalu hingga sekarang adalah mengenai Tuhan. Penyelidikan, penyidikan dan sekaligus penelitian terhadapnya telah melahirkan berbagai pandangan dan teori. Rasanya tidak berlebihan apabila dalam upaya mencari Tuhan telah berkembang menjadi sebuah ilmu yang kemudian dikenal dengan sebutan teologi.

Sebenarnya bukanlah maksud penulis untuk melibatkan diri ke dalam pergulatan pencarian Tuhan. Namun setidaknya guna memahami titik persoalan yang terkandung dalam teks Timbangan "proses" pencarian tentang Tuhan mutlak diperlukan. Bahkan menurut Al-Jisr (1976:33) mereka yang terlibat dalam upaya pembahasan tentang Tuhan, hakekatnya mereka telah memasuki dunia filsafat. Oleh karena filsafat hakikatnya dan selamanya membahas tentang Tuhan.

Teks Timbangan sebenarnya membangun pengertian Tuhan dalam persepsi ajaran Islam. Dalam prosesnya, sang penulis teks, mengetengahkan uraiannya bertitik tolak pada pengenalan diri pribadi manusia. Kenalilah diri sendiri; sebab dengan mengenali diri pribadi akan membawa dirinya mengenali Tuhan yang sebenarnya. Dalam lingkup lebih luas lagi, terutama dalam kaitannya dengan ibadah kepada Allah, pengenalan kepada-Nya menjadi lebih penting, bahkan terkesan sangat mendasar. Sebuah pertanyaan, mungkin, telah cukup menghentakkan kita untuk berpikir lebih mendalam. Misalnya siapakah Tuhan itu ? Jika kita tidak tahu jawabannya, maka implikasinya adalah kesia-siaan beribadah. Apalah artinya shalat, menyembah Allah, jikalau yang disembahnya tidak kita kenali. Oleh karena itulah, di dalam teks Timbangan bagian (2) Ibtat dikemukakan dalam pupuh Dangdanggula bait 3.

marifatna mungguh maha suci suci tina saniskara tekad tekad badag tekad awon awon lamun henteu jucung jucungkeun sing awas tingali tingali dina lafad man arofa nafsahu jeung faqod arofa robah saha-saha nu ngeunteung ka badan pribadi marifat ka Gustina

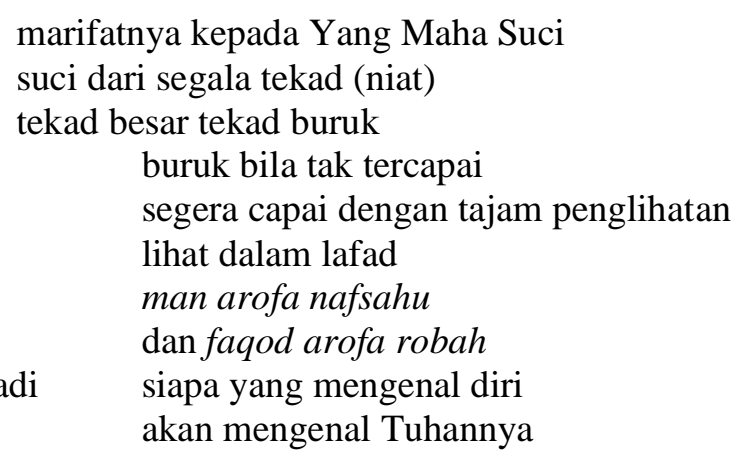

Senada dengan maksud di atas, Umarie (tt:18) memperjelas dengan menyatakan bahwa "Awwalu waajibin 'alal insaani, ma'rifatul ilaahi bistieqaani". Artinya : mula-mula pekerjaan yang wajib atas manusia yang Islam itu, ialah mengenal Allah dengan keyakinan. Dalam upaya mengenal Allah pun harus disikapi dengan cara yang elegan tidak seperti kita mengenal seseorang. Sebab Allah bersifat Laesa kamislihi syaiun, Tak ada sesuatu yang menyerupainya. 
Hamka (1987:17) mengklasifikasikan upaya pencarian diri untuk mengenal Allah ke dalam lingkup Tasauf. Menurutnya, jalan Tasauf ialah merenung ke dalam diri sendiri. Membersihkan diri dan melatihnya dengan berbagai macam latihan, riadlatun nafs, sehingga kian lama kian terbuka selubung diri itu dan timbullah cahayanya yang gemilang, yang dapat menembus segala hijab yang menyelubunginya selama ini. Socrates pun menyuruh orang untuk kembali menyelidiki dirinya sendiri, "Kenalilah dirimu!". Maka dalam kalangan tasuf timbullah pepatah yang terkenal : man araf nafsahu faqod araf rabbahu, "Barangsiapa yang mengenal akan dirinya niscaya kenallah ia akan Tuhannya".

\section{f. Sumber Ajaran}

Marilah kita sepakati dan bertitik tolak pada pertanyaan-pertanyaan mendasar dari sebuah filsafat metafisika yang mempertanyakan tentang hidup dan kehidupan di dunia ini. Pertanyaan yang sering diajukan ketika mempelajari filsafat adalah: Siapa aku ? Bagaimana ? Mau kemana ? Untuk apa dan Mengapa ? Dan ternyata pertanyaan-pertanyaan ini telah melahirkan berjilid-jilid buku dan berbagai aliran filsafat. Bahkan Syekh Abu Al-Mauzun (dalam Al-Jisr,1976:25-26) ketika disodorkan pertanyaan tersebut oleh muridnya Hairan bin Abudullah al-Adl'af, beliau tidak mampu menanggung keterkejutan yang amat sangat yang menyebabkan beliau tak sadarkan diri.

Dalam pada itu "daftar pertanyaan" yang dimaksud tampaknya merupakan pertanyaan universal yang ada pada setiap manusia (baca: bangsa). Bukankah dalam kalangan sufi pun terkenal ungkapan Qod arofa nafsahu, faqod arofa robbahu, barang siapa mengenal dirinya sendiri, maka ia akan mengenal Tuhannya. Dalil ini merupakan jalan pertama di dalam menyelami ilmu ketahuidan yang harus dikuasai oleh seseorang yang ingin mensucikan diri. Lepas dari masalah itu semua, hal pencarian diri di dalam rangka mencapai "ketenangan dan kedamaian" guna mengarah kepada kedekatan dengan sang Pencipta alam semesta banyak dilakukan melalui pengkajian diri sendiri sebagaimana telah dikemukakan.

Pencapaian jati diri manusia itu pun tak akan bermakna apa-apa tanpa pencapaian pengakuan kepada Sang Khalik. Artinya proses pencarian jati diri manusia harus dan -mungkin wajib- bermuara pada keyakinan adanya Tuhan. Keyakinan kepada adanya Tuhan ini secara tidak langsung akan melahirkan pula konsep-konsep ketuhanan. Dalam hubungannya dengan inilah hendaknya budaya diartikan sebagai upaya melahirkan konsep-konsep ketuhanan.

Teks Timbangan tidak secara eksplisit menyebutkan sumber ajaran yang menjadi materi bahasannya. Namun dengan menelaah pokok-pokok bahasannya, semuanya merujuk pada sumber ajaran umat Islam, yaitu Al-Quran dan Al-Hadits. Apa yang dikemukakan dalam pembahasan rukun Islam, dan sifat dua puluh semuanya tertera dalam Al-Quran dan Al-Hadits. Beberapa ayat dalam surat-surat tertentu dalam Al-Quran mengemukakan mengenai sifat-sifat 
Allah. Misalnya, dalam S. Al-Hadid (57 : 3): Dialah Yang Awal dan Yang Akhir Yang Zhahir dan Yang Bathin; dan Dia Maha Mengetahui segala sesuatu (Huwal awwalu wal akhiru wadhohiiru wal baathin wa huwa bikulli syaiin aliim).

Dalam pada itu sebagian teks Timbangan dapat dirujuk pada sumber ajarannya yaitu AlQuran. Teks yang dimaksud adalah sebagai berikut:

1) Bagian kedua Ibtat :

(1) Pupuh Dangdanggula bait 11; kawasana gusti maha suci, ka jelema ragrag pirangpirang, dalil-dalil nu araheng, ku ibtat di sebut, iqro kitabaka na dalil, jeung kafa binafsika, ku ibtat disambung, yaoma anta hasiba, geura buka kitab kurungan pribadi, nu aya di manehna. Maksud teks ini dapat dirunut pada QS. Al Israa' (17:14): "Bacalah kitabmu, cukuplah dirimu sendiri pada waktu itu sebagai penghisab terhadapmu".

(2) Pupuh Dangdanggula bait 12: nu nyukupan ka manehna pasti, pasti nyukupan kurungan, kurungan eta kitab teh, falyaoma latudz lamu, malah saterasna teh ditambih, nafsun saeaw walatudz jaona, ila ma kuntum, tamalun deui tambahna semet poe ieu ayeuna teh aing, ka maneh teu rek nyiksa. Kandungannya sebagaimana terdapat dalam QS. Yaasiin (36: 54): "Maka pada hari itu seseorang tidak akan dirugikan sedikitpun dan kamu tidak dibalasi, kecuali dengan apa yang telah kamu kerjakan"

2) Bagian ketiga Satahama

(1) Pupuh Sinom bait 12: Ari mungguh nu utama, nyaho azasna agami, cinta betah jeung sasama, turut parentahna Nabi, nu disebut dina dalil, almuminuna ikhwatun, kabeh mukmin dulur tunggal, ngagulung jadi sabani, bani Adam pokona jalma ayeuna. Kandungan teks bersumber pada QS. Al-Hujuraat(49:10): "Sesungguhnya orang-orang mu'min adalah bersaudara karena itu damaikan antara kedua saudaramu dan bertakwalah kepada Allah supaya kamu mendapat rahmat".

(2) Pupuh Asmarandana bait 25: sidik dina surat Yasin, mungguh nu Maha kawasa, kuma tingkah polah maneh, tingkah salah jadi nyiksa, nu hade jadi ganjaran, moal manggih deui hukum, lian ti jieun manehna. Kandungan teks bersumber pada QS. Yaasiin (36: 54) "Maka pada hari itu seseorang tidak akan dirugikan sedikitpun dan kamu tidak dibalasi, kecuali dengan apa yang telah kamu kerjakan".

(3) Pupuh Sinom bait 12 : Sidikna amantubillah, ti wa malaikatihi, kakara rasa sugema, mun nungtik wa kutubihi, tigin dina wa rasulihi, tutup catur tutup ilmu, wa bil yaomil akhiri, pameakan dunyawiyah, panganggeusan panutupan panginditan. Kandungan teks bersumber pada QS. Al-Baqarah (2:285): "Rasul telah beriman kepada Al-Quran yang diturunkan kepadanya dari Tuhannya, demikian pula orang-orang yang beriman. Semuanya beriman kepada Allah, malaikat-malaikat-Nya. (Mereka mengatakan): "Kami tidak membeda- 
bedakan antara seseorang pun (dengan yang lain) dari rasul-rasul-Nya", dan mereka mengatakan: "Kami dengar dan kami taat". (Mereka berdo'a): "Ampunilah kami ya Tuhan kami dan kepada Engkaulah tempat kembali".

\section{PENUTUP}

Ameng Timbangan yang mengidentiKkan sebagai "bela diri anti-kekerasan" berpijak pada konsep kemanusiaan yang bertakwa kepada Allah. Ketabuan mencelakakan, merusak, dan berbuat buruk kepada orang, sekalipun lawannya, merupakan buah atas pemahaman sifat-sifat Allah. Sifat-sifat Allah yang dipelajari dalam teks, terutama bagian Guaroma, merupakan gerbang pengamalan aturan-aturan hidup yang bersumber pada Al-Quran dan Al-Hadits.

Setiap manusia (mukmin) adalah saudara dan menjadi pijakan dalam berinteraksi. Hal itu kemudian harus dikembangkan dalam bentuk tolong-menolong, bantu-membantu antarsesama. Oleh karena itu, dalam gerak Ameng Timbangan hal yang mesti muncul adalah niat untuk menyelamatkan saudaranya (lawannya). Tidak terbesit sedikitpun niat untuk mencelakakannya, jika hal itu terjadi, maka Ameng Timbangan sebagai sistem "antikekerasan" sudah ternoda. Sumber utama teks Timbangan adalah Al-Quran dan al-Hadits .

\section{DAFTAR SUMBER}

\section{Buku}

Al-Jisr ,Syekh Nadim terjemahan A. Hanafi, MA.1976.

Kisah Mencari Tuhan I. Jakarta: Bulan Bintang.

Darmana, Nana dkk. 1978.

Aliran-aliran Pokok Pencak Silat Jawa Barat . Proyek Penelitian dan Pencatatan Kebudayaan Daerah Departemen Pendidikan dan Kebudayaan.

Ekajati, Edi S. 2010.

Nu Maranggung dina Sajarah Sunda. Bandung: Kiblat - Yayasan Pusat Studi Sunda, Fadilakusumah, A. Adil. 1997.

Penca. Bandung: Dinas Pendidikan dan Kebudayaan Provinsi Daerah TK I Jawa Barat. HAMKA,1987.

Pelajaran Agama Islam. Jakarta: Bulan Bintang.

Heryana, Agus. 1995.

Pencak Silat Aliran Cimande di Jawa Barat. Bandung: Balai Kajian Sejarah dan Nilai Tradisional

Heryana, Agus. 1995.

Laporan penelitian Pengkajian Kekuatan Tenaga Dalam pada Pencak Silat. Bandung: Balai Kajian Sejarah dan Nilai Tradisional (tidak diterbitkan) 
Rosidi,Ajip. 1966.

Kesusastraan Sunda Dewasa Ini. Ciebon: Tjupumanik.

Rauf, Abdur dan M. Rusman Tabrizy.1990.

Cikalong. Cianjur: Paguron Pusaka Cikalong Pusat Pasar Baru Cianjur

Rusyana, Yus. 1996,

Tuturan tentang Pencak Silat Dalam Tradisi Lisan Sunda. Jakarta: Yayasan Obor Indonesia.

Soepandi,Atik.1983.

Pupuh. Bandung: Pelita Masa

Umarie, Barmawie. t.t.

Sistematik Tasawwuf. Solo-Semarang: Ramadhani

\section{Artikel}

Bratakoesoemah,Ema.

Penca (14). Kudjang TAUN V No. 255 Jumaah 2 Desember 1960

Penca (15). Kudjang TAUN V No. 256 Jumaah 9 Desember 1960

Penca (16). Kudjang TAUN V No. 257 Jumaah 16 Desember 1960

Catatan Keluarga Besar Padepokan Penca Daya Sunda dalam bentuk stensilan tanpa tahun.

IPSI, 1990

Penyebaran dan Perkembangan Pencak Silat di Dunia Internasional.

Al-Quran dan Terjemahnya.

Wakaf dari Pelayan Dua Tanah Suci Raja Abdullah bin Abdul Azis Ali Sa'ud.

Mujamma'al Al-Malik Fahd li Thiba'at al-Mush-haf Asy-Syarif Madinah al-

Munawwarah P.O. Box 6262 Kerajaan Arab Saudi. 